\title{
NOTE ON THE PTEROSAUR MATERIAL DESCRIBED BY WOODWARD FROM THE RECÔNCAVO BASIN, LOWER CRETACEOUS, BRAZIL
}

\author{
TAISSA RODRIGUES \& ALEXANDER WILHELMARMIN KELLNER
}

Setor de Paleovertebrados, Departamento de Geologia e Paleontologia, Museu Nacional/UFRJ, Quinta da Boa Vista s/n, 20940-040, Rio de Janeiro, RJ, Brazil.taissa.rodrigues@gmail.com, kellner@mn.ufrj.br

\begin{abstract}
The reported occurrences of pterosaur specimens from the Lower Cretaceous Recôncavo Basin (Bahia), northeastern Brazil, is reviewed herein. All material was described by the British paleontologist A. S. Woodward and is housed at the Natural History Museum in London. The review confirms that all isolated and incomplete quadrates first regarded by Woodward as pterosaurian were later correctly referred to an osteichthyan coelacanthid species, and possibly represent Mawsonia gigas. Two isolated teeth were also found, one of which (BMNH R 8662) is likely the one briefly mentioned by Woodward in 1907 as pterosaurian. Those specimens, described and figured here for the first time, belong to a pterodactyloid pterosaur with affinities to the Anhangueridae. Despite not presenting new morphological data, the pterosaur tooth BMNH R 8662 is of historical importance since it is the first pterosaur from South America to be recorded in the literature. Furthermore, this material shows the presence of anhanguerid-like pterosaurs in the Lower Cretaceous of Bahia, extending the geographical record of this group in Brazil.
\end{abstract}

Key words: Pterosauria, Anhangueridae?, coelacanth, Cretaceous, Recôncavo Basin, northeastern Brazil.

\begin{abstract}
RESUMO - A ocorrência de pterossauros na bacia do Recôncavo (Cretáceo Inferior, Bahia), nordeste do Brasil, é revisada. Todo o material foi descrito por A. S. Woodward e se encontra tombado no Natural History Museum em Londres. Confirmou-se que todos os quadrados encontrados incompletos e isolados, a princípio considerados por Woodward como pterossauros, foram posteriormente corretamente referidos a uma espécie de celacantídeo, e possivelmente representam Mawsonia gigas. Dois dentes isolados também foram encontrados, sendo um deles provavelmente o exemplar mencionado brevemente como pertencente a um pterossauro por Woodward, em 1907. Estes espécimes, figurados e descritos aqui pela primeira vez, pertencem a um pterossauro pterodactilóide com afinidades ao clado Anhangueridae. Apesar de não apresentar novos dados morfológicos, o dente BMNH 8662 é de importância histórica por ter sido o primeiro exemplar de pterossauro da América do Sul a ser mencionado na literatura. Além disso, este material demonstra a presença de pterossauros similares a Anhangueridae no Cretáceo Inferior da Bahia, ampliando o registro geográfico deste grupo no Brasil.
\end{abstract}

Palavras-chave: Pterosauria, Anhangueridae?, celacanto, Cretáceo, bacia do Recôncavo, nordeste do Brasil.

\section{INTRODUCTION}

To date, the occurrence of pterosaur remains from the Lower Cretaceous Recôncavo Basin in the State of Bahia, northeastern Brazil, is considered controversial. Woodward (1891) described two incomplete quadrate bones from this unit as pterosaurian, pointing out that they were similar to "Rhamphorhynchus manseli," known from the Solnhofen Limestone (Upper Jurassic of Germany). This was the first alleged record of those Mesozoic flying reptiles from the southern hemisphere. Later, Woodward (1896) referred a three times larger quadrate from the same unit to a giant pterosaur. Mawson \& Woodward (1907) published a new contribution on the fossils from the Cretaceous of Bahia, with two subdivisions. The section on stratigraphy was written by Mawson and the review of the vertebrate fossils, by Woodward. In this work, Woodward studied more complete material from the area and realized that the large quadrate actually belonged to a coelacanthid fish, which he named Mawsonia gigas Woodward, 1907 (Mawson \& Woodward, 1907). In the same publication, he maintained the pterosaurian nature of the bones he had described in 1891, regarding them as "pterosaurian indet." (Mawson \& Woodward, 1907:131), and further added a "typical pterosaurian tooth" from the same locality (Mawson \& Woodward, 1907:131). Zittel (1932) mentioned the presence of a pterosaur quadrate from Bahia, but nothing was discussed about the quadrates; this is somewhat surprising since the English version of the book was revised by Woodward. Based on this, Price (1953) considered the referral of the bones and tooth to pterosaurs as doubtful but pointed out the potential of the deposits from the Recôncavo Basin to bear pterosaur fossils. Carvalho \& Maisey (2008:113), although not examining the quadrates first-hand, considered the bones as representing Mawsonia gigas. 
Campos (1983) reported a possible pterosaur tooth from the Recôncavo Basin, present in the collection of Orville A. Derby, housed at the Museu Nacional/Universidade Federal do Rio de Janeiro. Based on this information, Campos \& Kellner (1985) regarded the occurrence of pterosaurs in the Reconcâvo Basin possible but not certain. Examination of the fossil collection of this institution, however, revealed no such material. Furthermore, Kellner (1990) was not able to find Woodward's material at the Natural History Museum (London) and considered them lost. Since then, the pterosaur record of Bahia was largely disregarded (Price, 1953; Kellner, 1990; Barrett et al., 2008, recently cited them as ?Pterosauria indet.) and the identifications of Woodward (1896) discredited, particularly due to the wrong referral of the large coelacanthid quadrate as pterosaurian.

In September 2007, the examination of the pterosaur collection at the Natural History Museum (London) revealed three isolated quadrate bones (BMNH R 2119, 2120 and 2121) and one tooth (BMNH R 8662) from the Recôncavo Basin. During the second visit to the collection, in October 2009, the curator (Dr. Lorna Steel) had found a second pterosaur tooth (BMNH R 3221) among some crocodilian teeth collected by Mawson in Bahia. Those specimens shed new light on the interpretation of the pterosaur occurrences in this unit and all material is reviewed here.

Institutional abbreviations. BMNH, Natural History Museum, London, England; BSP, Bayerische Staatssammlung für Paläontologie und historische Geologie, Munich, Germany; LINHM, Long Island Natural History Museum, New York, USA; SMNK, Staatliches Museum für Naturkunde, Karlsruhe; SOS, Jura Museum, Eichstätt Germany; UERJ, Universidade do Estado do Rio de Janeiro, Rio de Janeiro, Brazil; UFMA, Universidade Federal do Maranhão, São Luís, Brazil; URCA, Universidade Regional do Cariri, Crato, Brazil.

\section{GEOLOGICAL SETTING}

\section{Locality}

J. Mawson collected the fossils near the Bahia \& São Francisco and Timbó railways, as explained and mapped by him in 1907 (Mawson \& Woodward, 1907). The quadrates described in 1891 were referred to localities "between Plataforma and Itacaranha" and "from this beach or from Pedra Furada Bay (Montserrat).” According to his map, those places are nowadays in the city of Salvador. The locality of the "giant" quadrate was referred only as "in the same district" (Woodward, 1896:153); there is no information whether this refers to Salvador or if it could be from other localities near the railways in Bahia, visited by Mawson. Both pterosaur teeth come from Pedra Furada Bay (Mawson \& Woodward, 1907; BMNH collection information held with the specimens).

\section{Stratigraphy and age}

Despite the relatively good information on the localities where the fossils were found, no exact stratigraphic stratigraphic precedence was recorded by Mawson. Rocks from the Recôncavo Basin, Bahia Supergroup, crop out in those localities. The formations from which the material could have come have all been dated as Lower Cretaceous, based on microfossils (Viana et al., 1971). Only new geological works, following Mawson's notes, could recover all this historical information.

\section{DESCRIPTION AND COMPARISONS}

\section{Coelacanthid quadrates (BMNH R 2119, R 2120 and R 2121)}

Two left (BMNH R 2119 and 2121) and one right (BMNH $\mathrm{R} 2120$ ) isolated and incomplete fish quadrates were found in the pterosaur collection of the Natural History Museum (Figure 1). One (BMNH R 2119) was figured by Woodward (1891:fig. 2), at that time being considered as pterosaurian. This specimen shares the same collection information with BMNH R 2120, and it is possible that the latter was the second quadrate studied by Woodward (1891). The third specimen (BMNH R 2121) has the same general features as the other two, including size, so it is possibly another specimen that might not have been mentioned, probably not the "giant quadrate" reported by Woodward (1896).

All three bones (BMNH R 2119, 2120 and 2121) are fully prepared and composed essentially of their articulation surface with the lower jaw. There are two well-developed condyles, the inner being the largest, as typical of coelacanths (Carvalho, 2002). A well-defined incisura intercondylaris can also be seen and the anterior and posterior surfaces are rugose. The overall shape and ornamentation are congruent with that of other quadrates from Mawsonia gigas that have been unearthed from the Recôncavo Basin (Carvalho, 1976) and other Cretaceous sites in Brazil (Carvalho, 2002). The width at the condyles of BMNH R 2119, 2120 and 2121 are 18, 22 and $15 \mathrm{~mm}$, respectively, indicating individuals of medium size, in comparison to the Mawsonia gigas material studied by Carvalho (2002).

\section{Pterosaur teeth (BMNH R 8662 and R 3221)}

The tooth BMNH R 8662 (Figures 2,3) is the one found in the pterosaur collection in 2007, which was recently cited (but not figured) by Barrett et al. (2008) as ?Pterosaurian indet. This specimen is possibly the one cited by Woodward (Mawson \& Woodward, 1907). It is partially embedded in the matrix, and only one view is exposed, either the labial or lingual. As preserved, it is ca. $29 \mathrm{~mm}$ high and ca. $7 \mathrm{~mm}$ mesiodistally wide at its base. The crown is long, narrow, and uniformly curved. Longitudinal lines are present on the enamel that has a dark-brown color. No carinae are visible. The base shows an oval cross-section. The region of the root is broken and therefore it is not clear if the tooth was replaced or broken off the individual's jaw.

BMNH R 3221 is slightly larger than the above-mentioned one (31 mm high, Figure 4). It was until recently among some crocodilian teeth collected by Mawson in Bahia, when the curator retrieved it and moved it to the pterosaur collection. This specimen is completely freed from the matrix. As the enamel is not well preserved, the longitudinal lines are not visible, but the size and format are congruent with other 
pterosaur teeth (e.g. Anhangueridae, see comments below), including BMNH R 8662. The cross section is oval.

A quick examination showed that both teeth are easily discernible from the crocodilian teeth collected by Mawson in Bahia, which have strong longitudinal ridges that elevate from the surface of the enamel, differing form the longitudinal lines in the teeth described here. It is possible that other ones like those are still mixed with the crocodilian material.

Some fish taxa may have teeth with a similar overall morphology, such as Cladocyclus, Xiphactinus and other ichthyodectids (e.g. Forey \& Cavin, 2007), but they lack the longitudinal lines present in the ones described here.

The present specimens show the same characteristics as some pterosaur teeth (see comparisons below) and are therefore confidently referred to as pterosaurs. Comparison to more complete material from the Santana Group (Araripe Basin, northeastern Brazil) showed that they closely resemble anhanguerid teeth, such as the long and slender teeth of Anhanguera blittersdorffi Campos \& Kellner, 1985 (Pz-DBAVUERJ 40; Kellner \& Tomida, 2000:fig. 66b) from the Romualdo Formation (Aptian/Albian; Beurlen, 1971) and the possibly related Ludodactylus sibbicki Frey, Martill \& Buchy, 2003 (SMNK PAL 3828; Frey et al., 2003) (Figure 5) from the Crato Formation (Aptian; Beurlen, 1971), where the first teeth also show longitudinal lines, such as BMNH R 8662, and similar shape and curvature of the crown. It is noteworthy that this morphology is present in several pterosaurs from the Romualdo and Crato formations of the Araripe Basin.

BMNHR 8662 and BMNHR 3221 can be regarded as possibly representing species closely related or referable to the Anhangueridae. As already pointed out (e.g. Campos \& Kellner, 1985; Wellnhofer \& Buffetaut, 1999; Wang et al., 2009), anhanguerid teeth vary in morphology and size depending on their position, with the ones at the premaxillae and at the anterior tip of the dentaries being longer and slender. Since the reported teeth show those morphological features, they likely come from the anterior portion of the rostrum or mandible.

Kellner \& Mader (1997) have described an isolated tooth (LINHM 007; crown height $53 \mathrm{~mm}$ ) from the Cretaceous Kem Kem deposits of Morocco referred to the Anhangueridae or a closely related taxon. Despite being smaller than the African specimen, BMNH R 8662 shows the same features including the longitudinal lines.

Wellnhofer \& Buffetaut (1999) described approximately 30 pterosaur teeth from the Red Beds of Morocco and classified them into four morphotypes that were tentatively referred to the Ornithocheiridae. Some of those teeth bear a discrete carina that could not be positively identified in BMNH $\mathrm{R} 8662$, but the presence of carinae in pterosaur teeth and its systematic implications has yet to be investigated. The degree

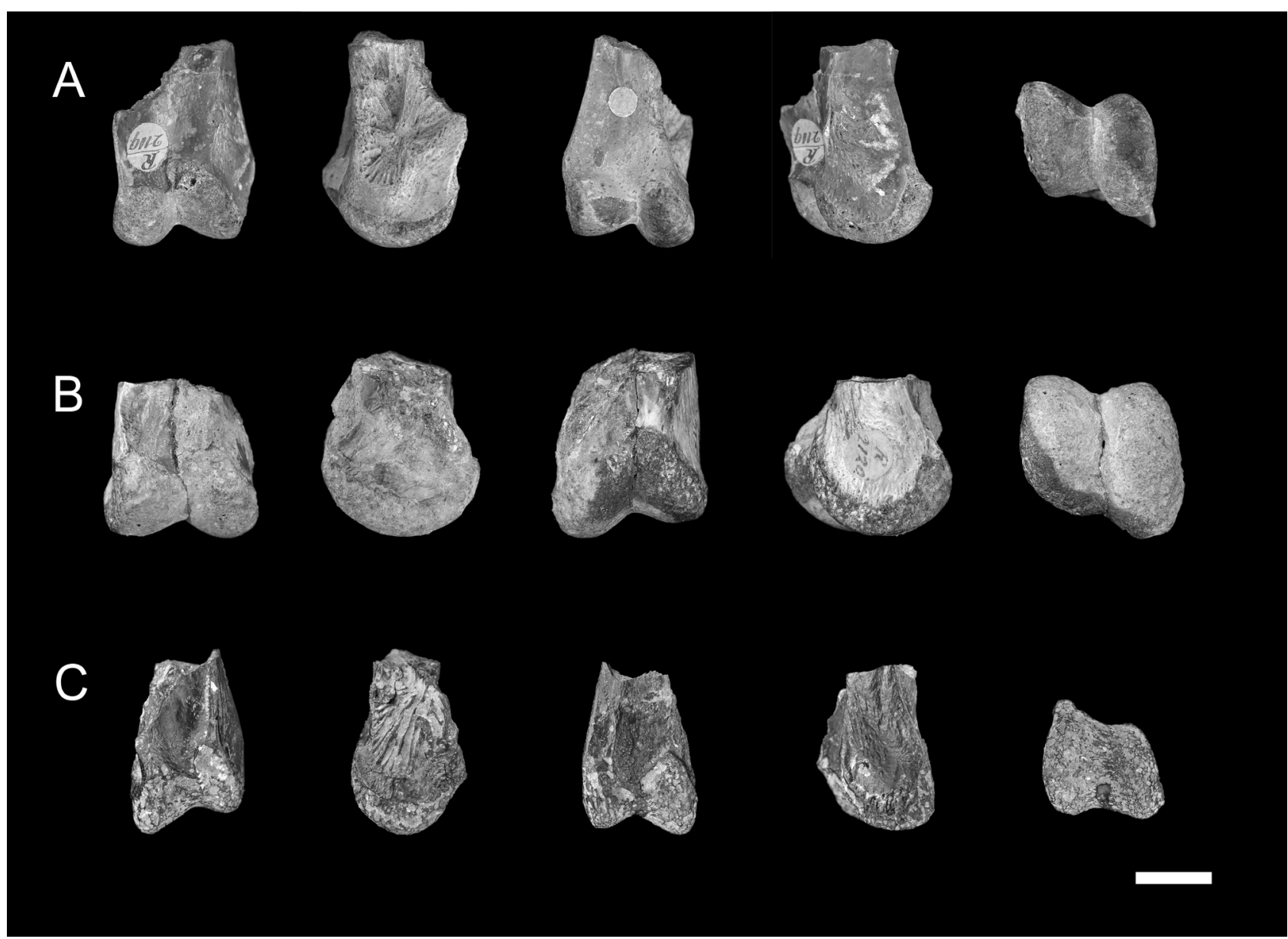

Figure 1. Mawsonia gigas (Osteichthyes, Coelacanthidae) quadrate bones from the Recôncavo Basin, Lower Cretaceous, in views (from left to right): lateral, anterior, mesial, posterior and distal. A, BMNH R 2119; B, BMNH R 2120; C, 2121. Scale bar = $10 \mathrm{~mm}$. 
of curvature and the presence of longitudinal lines up to the tip of the tooth crown in BMNH R 8662 is also observed in BSP 1993 IX 332, which was referred by Wellnhofer \& Buffetaut (1999) to their morphotype III.

Knoll (2000) described nearly 300 isolated teeth from the Lower Cretaceous calcareous lens in Morocco. They were divided into two morphotypes: the least abundant type was referred to as ornithocheirid, while the most abundant was identified as gnathosaurine. However, in Gnathosaurus subulatus von Meyer, 1833 (SOS 4580), the teeth are much more elongated and show a very distinctive curvature in the upper part of the crown (Figure 5), and at least some of the teeth referred to this morphotype could also represent an anhanguerid or a closely related taxon.

Other isolated pterosaur teeth have also been found in the Cretaceous of Brazil. Elias et al. (2007) described nine isolated teeth from the Laje do Coringa bone-bed, a site belonging to the Cenomanian Alcântara Formation, in Maranhão, northeastern Brazil, whose fossils tend to be isolated (Kellner et al., 2009). Those teeth were sorted into four morphotypes. As far as comparisons can be made, the curvature of BMNH R 8662 bears similarity to the specimens URC R.77-2 (morphotype 1, referred to the Anhangueridae)

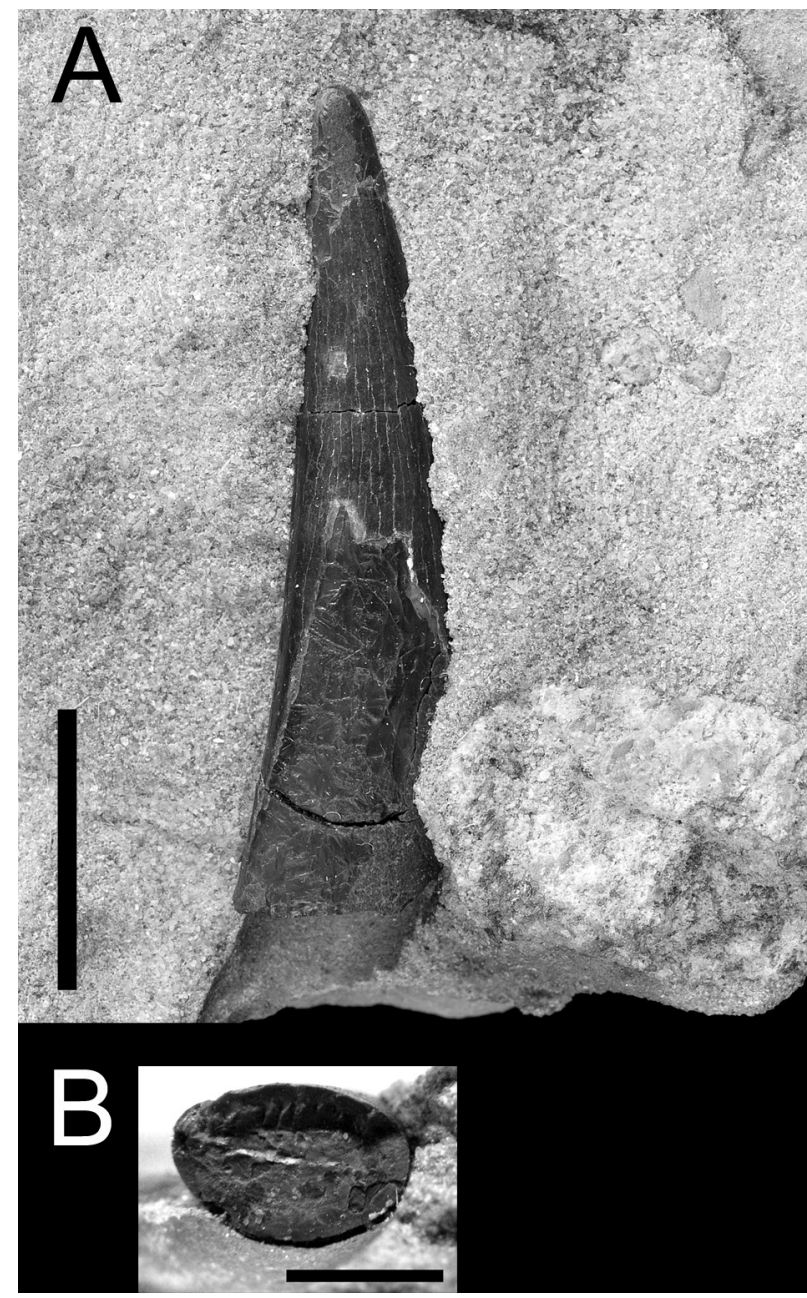

Figure 2. Pterosaur tooth (BMNH R 8662), from the Recôncavo Basin, Lower Cretaceous. A, lateral view; B, inset showing the base. Scale bars $=(B) 5 \mathrm{~mm},(A) 10 \mathrm{~mm}$. and UFMA 1.20.130 (morphotype 3, referred to the Ornithocheiroidea). However, UFMA 1.20.130 shows parallel wrinkles that are absent in BMNH R 8662, while the Alcântara specimens lack longitudinal lines on the enamel.

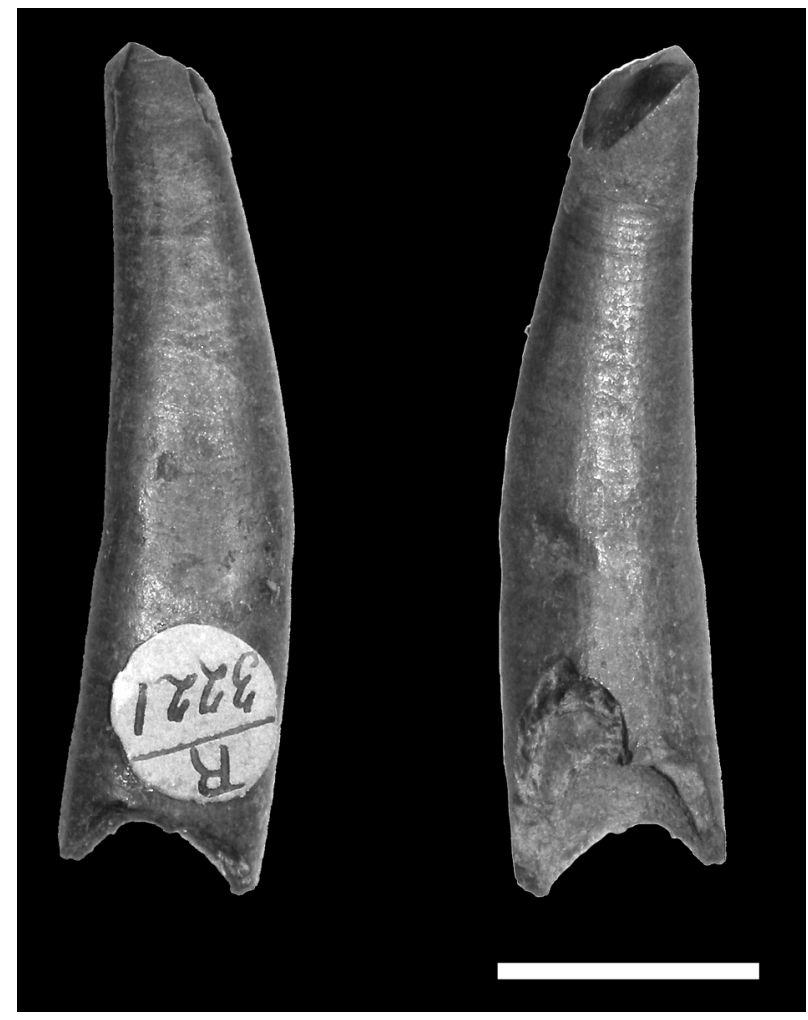

Figure 3. Pterosaur tooth (BMNH R 3221), from the Recôncavo Basin, Lower Cretaceous, in lateral views. Scale bar $=10 \mathrm{~mm}$.

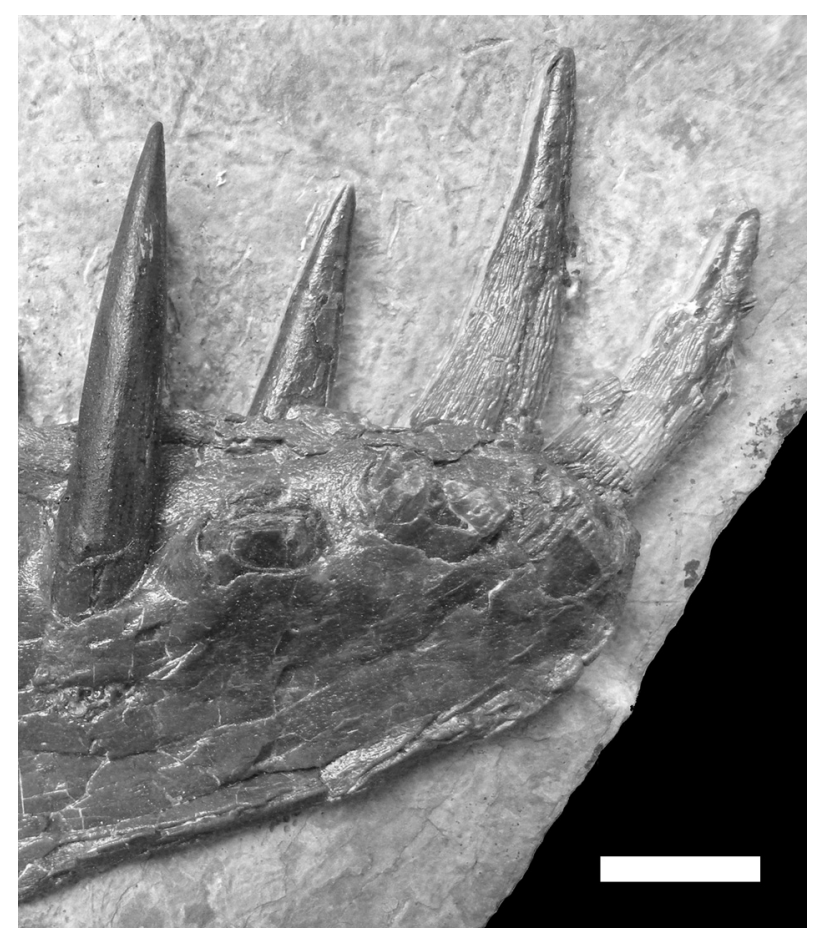

Figure 4. Anterior tip of the mandible of Ludodactylus sibbick (SMNK PAL 3828) from the Aptian Crato Formation in right lateral view. Scale bar $=10 \mathrm{~mm}$. 


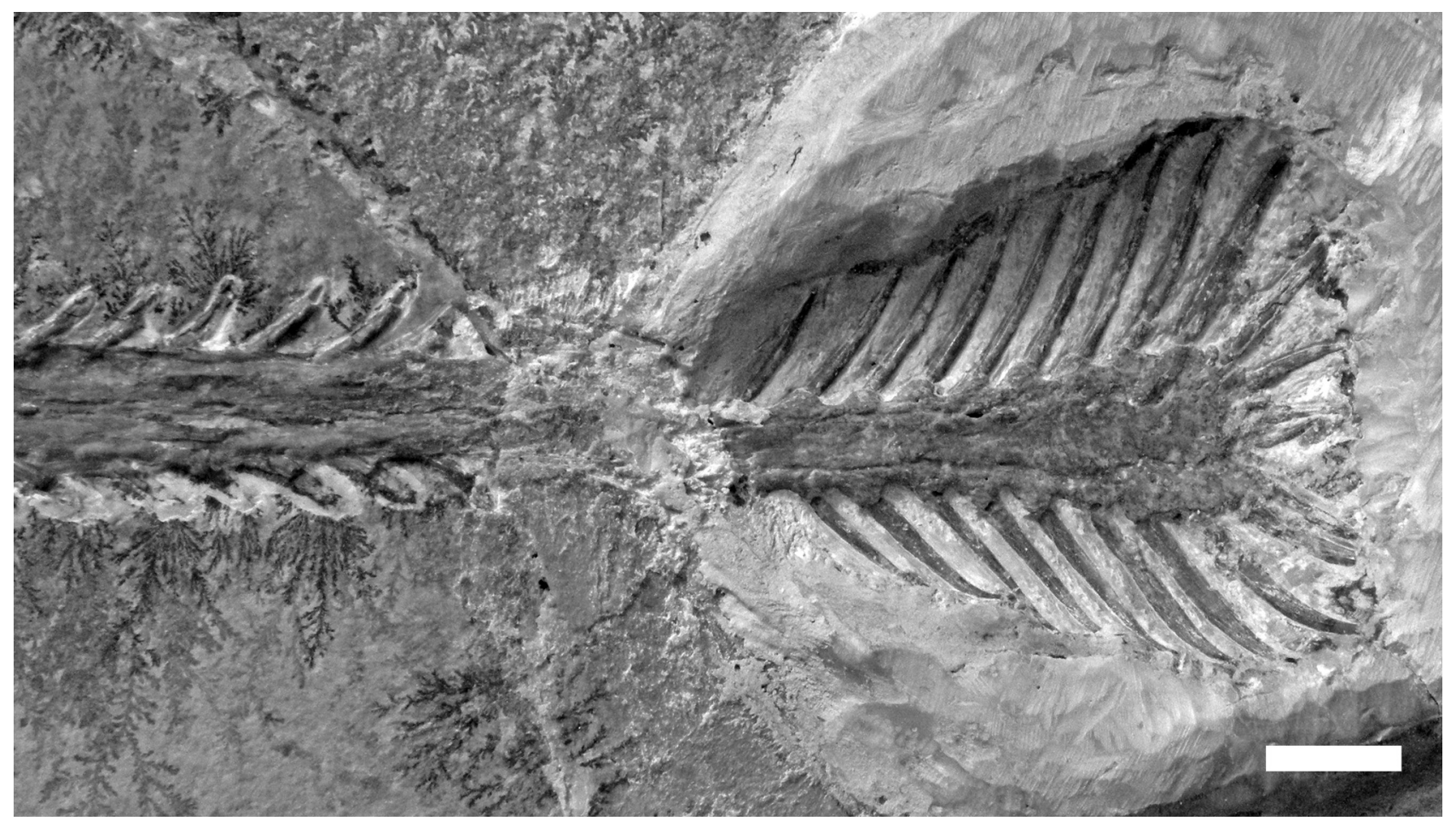

Figure 5. Tip of the rostrum of Gnathosaurus subulatus (SOS 4580) from the Upper Jurassic Solnhofen Limestone in palatal view. Scale bar $=10 \mathrm{~mm}$.

\section{CONCLUSIONS}

Although present in almost all continents, the pterosaur record is quite uneven when it comes to the completeness of the specimens. Even in deposits where delicate and rather complete material of other vertebrates is found, the presence of pterosaurs is limited to fragmentary and incomplete material (e.g. Calvo et al., 2007; Costa \& Kellner, 2009).

Pterosaurs exhibit a large diversity of teeth morphologies, and quite often those are characteristic of different clades (e.g. the Ctenochasmatidae, Istiodactylidae and Dsungaripteridae; Wellnhofer, 1978; Kellner, 2003). Therefore, isolated teeth can be and have been used, according to the literature, for the identification of the occurrence of pterosaurs in different deposits where osteological material is relatively rare or unknown. Some of those referrals, as cited above, concern the identification of anhanguerid (or sometimes referred as ornithocheirid) teeth. In at least one of those deposits, the Moroccan Kem Kem red beds, the presence of Anhangueridae was later confirmed by osteological evidence (a rostrum, which is the holotype of Siroccopteryx moroccensis Mader \& Kellner, 1999) (Mader \& Kellner, 1999).

Despite not presenting new morphological data, BMNH $\mathrm{R} 8662$ is of historical interest, as the first pterosaur discovered (only cited but not described) in South America, besides somehow redeeming Woodward's erroneous identifications regarding the quadrates. Therefore, the Gramame Formation humerus described by Price (1953) as the holotype of Nyctosaurus lamegoi would be, in fact, the second pterosaur material from the continent.

\section{ACKNOWLEDGMENTS}

We would like to thank A. Milner, S. Chapman and L. Steel (Natural History Museum), E. Frey (Staatliches Museum für Naturkunde Karlsruhe) and M. Kölbl-Ebert (Jura Museum) for access to the specimens under their care. The Natural History Museum kindly provided photos of the specimens deposited in the institution. Thanks go to S. Christopher Bennett and J.P. Billon-Bruyat for their reviews of the manuscript and to M. Carvalho, V. Gallo and A. LopezArbarello for observations regarding the quadrates. This study was partially funded by Conselho Nacional de Desenvolvimento Científico e Tecnológico (grants \# 140407/2007-3 and 290019/2008-7 awarded to T.R. and \#307276/2009-0 awarded to A.W.A.K.) and Fundação Carlos Chagas Filho de Amparo à Pesquisa do Rio de Janeiro (FAPERJ - grant \# E26/102.779/2008 awarded to A.W.A.K.). T.R. would also like to thank the Deutscher Akademischer Austauschdienst for partially supporting her Ph.D. studies in Germany.

\section{REFERENCES}

Barrett, P.M.; Butler, R.J.; Edwards, N.P. \& Milner, A.R. 2008. Pterosaur distribution in time and space: an atlas. Zitteliana $B$, 28:61-107.

Beurlen, K. 1971. As condições ecológicas e faciológicas da Formação Santana na Chapada do Araripe (Nordeste do Brasil). Anais da Academia Brasileira de Ciências, 43(supl.):411-415.

Calvo, J.O.; Porfiri, J.D.; González-Riga, B. \& Kellner, A.W.A. 2007. A new Cretaceous terrestrial ecosystem from Gondwana with the description of a new sauropod dinosaur. Anais da Academia Brasileira de Ciências, 79(3):529-541. 
Campos, D.A. 1983. Um novo pterossauro de Chapada do Araripe. Anais da Academia Brasileira de Ciências, 55(1):141-142.

Campos, D.A. \& Kellner, A.W.A. 1985. Panorama of the flying reptiles study in Brazil and South America. Anais da Academia Brasileira de Ciências, 57(4):453-466.

Carvalho, M.S.S. 1976. O gênero Mawsonia na ictiofáunula do Cretáceo do estado da Bahia. Programa de Pós-Graduação em Geologia, Universidade Federal do Rio de Janeiro, Dissertação de Mestrado, 84 p.

Carvalho, M.S.S. 2002. O gênero Mawsonia (Sarcopterygii, Actinistia) no Cretáceo das bacias Sanfranciscana, Tucano, Araripe, Parnaíba e São Luís. Programa de Pós-Graduação em Geologia, Universidade Federal do Rio de Janeiro, Tese de Doutorado, $177 \mathrm{p}$.

Carvalho, M.S.S. \& Maisey, J.G. 2008. New occurrence of Mawsonia (Sarcopterygii: Actinistia) from the Early Cretaceous of the Sanfranciscana Basin, Minas Gerais, southeastern Brazil. In: L. Cavin; A. Longbottom \& M. Richter (eds.) Fishes and the Break-up of Pangaea, Geological Society Special Publications 295, p. 109-144.

Costa, F.R. \& Kellner, A.W.A. 2009. On two pterosaur humeri from the Tendaguru beds (Upper Jurassic, Tanzania). Anais da Academia Brasileira de Ciências, 81(4):813-818.

Elias, F.A; Bertini, R.J. \& Medeiros, M.A.A. 2007. Pterosaur teeth from the Laje do Coringa, middle Cretaceous, São Luís-Grajaú Basin, Maranhão State, northern-northeastern Brazil. Revista Brasileira de Geociências, 37(4):1-9.

Forey, P.L. \& Cavin, L. 2007. A new species of Cladocyclus (Teleostei: Ichthyodectiformes) from the Cenomanian of Morocco. Palaeontologia Electronica, 10(3):12A.10 p.

Frey, E.; Martill, D.M. \& Buchy, M.-C. 2003. A new crested ornithocheirid from the Lower Cretaceous of northeastern Brazil and the unusual death of an unusual pterosaur. In: E. Buffetaut \& J.M. Mazin (eds.) Evolution and Palaeobiology of Pterosaurs, Geological Society Special Publications 217, p. 55-63.

Kellner, A.W.A. 1990. Os répteis voadores do Cretáceo brasileiro. Anuário do Instituto de Geociências, 12:86-106.

Kellner, A.W.A. 2003. Pterosaur phylogeny and comments on the evolutionary history of the group. In: E. Buffetaut \& J.M. Mazin (eds.) Evolution and Palaeobiology of Pterosaurs, Geological Society Special Publications 217, p. 105-137.

Kellner, A.W.A. \& Mader, B.J. 1997. Archosaur teeth from the Cretaceous of Morocco. Journal of Paleontology, 71(3):525-527.
Kellner, A.W.A. \& Tomida, Y. 2000. Description of a new species of Anhangueridae (Pterodactyloidea) with comments on the pterosaur fauna from the Santana Formation (Aptian-Albian), northeastern Brazil. National Science Museum Monographs, 17:1-135.

Kellner, A.W.A.; Pinheiro, A.E.P.; Azevedo, S.A.K.; Henriques, D.D.R.; Carvalho, L.B. \& Oliveira, G.R. 2009. A new crocodyliform from the Alcântara Formation (Cenomanian), Cajual Island, Brazil. Zootaxa, 2030:49-58.

Knoll, F. 2000. Pterosaurs from the Lower Cretaceous (?Berriasian) of Anoual, Morocco. Annales de Paléontologie, 86(3):157-164.

Mader, B.J. \& Kellner, A.W.A. 1999. A new anhanguerid pterosaur from the Cretaceous of Morocco. Boletim do Museu Nacional, Nova Série Geologia, 45:1-11.

Mawson, J. \& Woodward, A.S. 1907. On the Cretaceous Formation of Bahia (Brazil), and on the vertebrate fossils collected therein. Quarterly Journal of the Geological Society, 63:128-139.

Price, L.I. 1953. A presença de Pterosauria no Cretáceo Superior do estado da Paraíba. Notas Preliminares e Estudos, 71:1-10.

Viana, C.F.; Gama Junior, E.G.; Simões, I.A.; Moura, J.A.; Fonseca, J.R. \& Alves, R.J. 1971. Revisão estratigráfica da bacia Recôncavo/Tucano. Boletim Técnico da Petrobrás, 14(3/4):157192.

Wang, X.; Kellner, A.W.A.; Jiang, S. \& Meng, X. 2009. An unusual long-tailed pterosaur with elongated neck from western Liaoning. Anais da Academia Brasileira de Ciências, 81(4):793812.

Wellnhofer, P. 1978. Pterosauria. In: Handbuch der Palëoherpetologie, Gustav Fischer Verlag, 82 p. (Teil 19).

Wellnhofer, P. \& Buffetaut, E. 1999. Pterosaur remains from the Cretaceous of Morocco. Paläontologische Zeitschrift, 73(1/2):133-142.

Woodward, A.S. 1891. Evidence of the occurrence of pterosaurians and plesiosaurians in the Cretaceous of Brazil, discovered by Joseph Mawson, Esq., F. G. S. Annals and Magazine of Natural History, 6(8):314-317.

Woodward, A.S. 1896. On the quadrate bone of a gigantic pterodactyl discovered by Joseph Mawson, Esq., F. G. S., in the Cretaceous of Bahia, Brazil. Annals and Magazine of Natural History, 6(17):255-257.

Zittel, K.A. 1932. Text Book of Paleontology. $2^{\text {a }}$ ed. London, Macmillan and Co., vol. 2, 464 p.

Received in November, 2009; accepted in May, 2010. 